\title{
PENGARUH KONSELING KELOMPOK BEHAVIORAL DENGAN TEKNIK LATIHAN ASERTIF UNTUK MENINGKATKAN SELF - AWRENESS PERILAKU SEKS BEBAS PADA SISWA KELAS XI DI SMK 17 AGUSTUS 1945 MUNCAR TAHUN AJARAN 2017/2018
}

\author{
Nindia Agustin Fitriani ${ }^{1)}$, Endang Minarni ${ }^{2)}$ \\ Fakultas Keguruan dan Ilmu Pendidikan, Universitas PGRI Banyuwangi \\ email: nindiafitria1996@gmail.com \\ email: endangmr249@yahoo.co.id
}

\begin{abstract}
Free sex behavior is any means of expressing and releasing sexual urges derived from the maturity of sexual organs, such as intimate dating, flirting, to sexual contact that is judged not in accordance with the norm. It is therefore important for students to increase self-awareness. The purpose of this study was to determine the increase of self-awareness of free sex behavior in students of class XI in SMK 17 August 1945 Muncar after being given behavioral counseling with assertive training techniques. This research is a study of guidance and counseling actions. This research was conducted in two cycles, involving students of class XI SMK 17 August 1945 Muncar which amounted to 20 people as research subjects. The 20 students were given treatment through behavioral counseling with assertive training techniques implemented in group counseling. This research method uses non equivalent PretestPosttest Control Group Design design.
\end{abstract}

Keywords :Behavioral group counseling, assertive training, free sex behavior

\section{PENDAHULUAN}

Di era modern seperti sekarang ini, pergaulan bebas merupakan fenomena yang tidak asing lagi. Pergaulan bebas dapat didefinisikan sebagai melencengnya pergaulan seseorang dari pergaulan yang benar, pergaulan bebas diidentikkan sebagai bentuk dari pergaulan luar batas dan sering dihubungkan dengan perilaku seks bebas.

Perilaku seks pada remaja di Indonesia saat ini menjadi ancaman. Di Indonesia terdapat $26,67 \%$ dari jumlah penduduk sebesar 237,6 adalah kelompok usia muda (10-24 tahun). Walaupun seks pra-nikah tidak diterima dimasyarakat, namun tidak menutup kemungkinan tidak adanya kasus atau kejadian. Menurut SDKI (Survei Demografi dan Kesehatan Indonesia, 2007) menyatakan bahwa remaja belum menikah yang melakukan hubungan seks, secara umum lebih banyak wanita dibanding dengan pria. Sebanyak $38 \%$ wanita muda dan $12 \%$ pria muda melakukan hubungan seks pranikah dibawah umur 18 tahun. Hal yang sangat mengkhawatirkan adalah untuk berbagai alasan yang diberikan selama survei, remaja laki-laki lebih muda (15-19 tahun) lebih menyetujui hubungan seks pranikah 
dibandingkan dengan remaja laki-laki usia lebih tua (20-24 tahun) (Pinem, 2009).

Hasil survey kesehatan reproduksi remaja (14-19 tahun) tahun 2009 tentang perilaku seksual remaja terhadap kesehatan reproduksi remaja menunjukkan : dari 19.173 responden 92\% sudah pernah berpacaran. Pada saat berpacaran melakukan pegang-pegangan tangan, $82 \%$ ciuman, 62\% melakukan petting, dan 10,2\% melakukan hubungan seks bebas di Jabotabek. Data tersebut diperkuat oleh BKKBN tahun 2010 yang mengungkapkan bahwa dari 100 responden di Jabotabek $51 \%$ remaja sudah pernah melakukan hubungan seks pranikah. Di Surabaya 54\%, Bandung 47\%, Medan 52\%, Yogya 37\%. Hal ini ditengarai sebagai dampak dari pergaulan dengan teman sebaya yang bernuansa perilaku seks bebas yang melanda remaja (Suryanto \& Kuswatono, 2010).

Menurut Sarwono (2011), perilaku seksual adalah segala tingkah laku yang didorong oleh hasrat seksual, baik dengan lawan jenisnya maupun dengan sesama jenis. Bentuk-bentuk tingkah laku ini bisa bermacam-macam, mulai dari membaca buku porno, nonton film porno, perasaan tertarik sampai tingkah laku berkencan, bercumbu, dan bersenggama. Perilaku seksual ini lebih baik diketahui dari orang tuanya, dari pada si anak mendapatkannya dari pendapat atau khayalan sendiri, teman, buku-buku, atau pun film-film porno yang kini dapat di akses secara bebas. Khayalan itu bisa saja membuat mereka menyalahgunakan arti dan fungsi organ seksualnya, maka salah satu yang mungkin bisa mengontrol perilaku seksual anak saat beranjak remaja adalah monitoring orang tua. Jadi orang tua mempunyai peranan penting karena yang pertama sekali saat anak beranjak remaja tumbuh di keluarganya sendiri. Artinya orang tua harus menyediakan waktu yang ekstra untuk memperhatikan anak remajanya terutama dalam perilaku seksual (Dianawati, 2003). Masa remaja merupakan masa dimana terjadi transisi masa kanak-kanak menuju dewasa, berkisar antara usia 13 sampai 20 tahun (Potter \&Perry, 2009). Masa ini tidak hanya menjanjikan kesempatan untuk menuju kehidupan yang berhasil dimasa depan tetapi juga menawarkan risiko terpaparnya masalah kesehatan.

Perubahan fisik masa remaja terutama ditandai dengan perubahan seks primer dan perubahan seks sekunder. Perubahan seks sekunder yang terjadi pada masa remaja berkaitan dengan hormon seksual yang berperan terhadap fungsi reproduksi (Depkes, 2010). Kematangan pada organorgan reproduksi dan perubahanperubahan hormonal menyebabkan munculnya dorongan-dorongan seksual pada masa remaja (Desmita, 2009). Adanya dorongan-dorongan seksual dan 
ketertarikannya dengan lawan jenis kelaminnya menyebabkan perilaku remaja mulai diarahkan kepada minat terhadap kehidupan seksual (Kusmiran, 2011). Hal ini menjadi titik rawan karena remaja mempunyai kecenderungan untuk mencoba hal-hal yang belum diketahuinya berkaitan dengan perubahan yang dialaminya sehingga diharapkan perlu informasi yang positif ke remaja (Depkes RI, 2011). Survei yang dilakukan Kesehatan Reproduksi Remaja Indonesia (SKRRI) pada tahun 2007 mendapatkan data bahwa perilaku seks bebas bukanlah sesuatu yang aneh dalam kehidupan remaja Indonesia. Pada remaja laki-laki didapatkan data yang pernah melakukan hubungan seksual sebelum menikah, 6,4 persen remaja laki-laki dan 1,3 persen remaja perempuan (SKRRI, 2007). Studi pendahuluan yang dilakukan oleh peneliti pada bulan Juli 2014 di LP Anak Kelas (II) Kota Blitar, terhadap 10 orang remaja dari 104 narapidana anak selaku pidana pelaku pelecehan seksual dari bulan Januari sampai Mei tahun 2014.

Dengan adanya berbagai fenomena pergaulan bebas di kalangan remaja yang semakin banyak terjadi, membuat orang tua semakin khawatir dengan perilaku seks para remaja mereka. Namun, seharusnya remaja mampu menyelesaikan tugas perkembangan seksualitas mereka dengan baik. Karena bukan saja dapat menimbulkan kehamilan, tapi perilaku seks yang salah dan sebelum waktunya seperti itu juga dapat memperbesar resiko tertularnya banyak penyakit seksual.

Remaja dalam menentukan sikap sebaiknya bersikap mandiri, tegas, dan bebas. Remaja dapat mengambil keputusan sesuai dengan keinginan tanpa harus membatasi diri, dan dapat menentukan apa yang terbaik untuk dirinya sendiri. Sikap remaja tersebut sebagai perilaku asertif remaja. Asertif dari kata assertive yang berarti tegas dalam pernyataan, pasti dalam mengekspresikan diri dan pendapatnya (Bayuwati, 2005). Chaplin (2001) menyatakan bahwa assertiveness adalah kondisi individual yang tidak pasif atau takut pada situasi tertentu. Asertif juga disebut mengekspresikan diri secara jujur dengan cara tepat tanpa perasaan cemas yang mengganggu, sehingga mendorong terwujudnya kesejahteraan dan persamaan dalam dengan pasangannya (Lubis \& Oriza, 2000).

Banyaknya permasalahan remaja terkait seks bebas sangatlah diperlukan untuk mencegah dan mengobati para pelaku seks bebas, hal ini bisa dengan diberikan bimbingan dan arahan yang positif. Dalam konteks ini peneliti memberikan konseling behavioral teknik asertif, karena peneliti menginterpretasikan bahwa teori ini sangat cocok dengan keadaan individu yang mengalami pergaulan bebas atau seks bebas. 
Konseling behavioral merupakan proses membantu orang untuk belajar bagaimana memecahkan suatu masalah tertentu baik itu masalah interpersonal, emosional, dan masalah keputusan. Sedangkan, teknik latihan asertif merupakan latihan keterampilan sosial agar seseorang mampu mengungkapkan ekspresi langsung, jujur dan pada tempatnya dari pikiran, perasaan, kebutuhan, atau hakhak seseorang tanpa kecemasan yang beralasan

Dengan pelaksanaan konseling behavioral dengan teknik asertif ini, diharapkan para remaja mampu bersikap tegas dalam mempertahankan hak seksualnya untuk Perilaku seks bebas merupakan sebuah kritik sosial yang sangat mencemaskan orang tua, pendidik, ulama, tokoh masyarakat serta aparat pemerintah. Salah satu perilaku seks bebas yang dilakukan oleh remaja adalah necking. Necking secara sederhana dapat diartikan ciuman leher. Tahapan - tahapan konseling kelompok pada umumnya ada empat tahap perkembangan dalam konseling kelompok, yaitu:

1) Tahap pembentukan

2) Tahap peralihan

3) Tahap pelaksanaan kegiatan

4) Tahap pengakhiran.

Masing- masing tahap tersebut memiliki karakteristik tertentu (Prayitno,2004). tidak dilecehkan dan dapat mengambil keputusan seksualnya dengan tetap memberi penghargaan atas hak orang lain dan tanpa menyakiti orang lain atau pasangannya.

Berdasarkan latar belakang yang telah disampaikan di atas, maka dari itu penulis akan melakukan penelitian dengan judul Pengaruh Konseling Behavioral Dengan Teknik Latihan Asertif Untuk Meningktkan Self - Awarness Perilaku Seks Bebas Pada Siswa Kelas XI Di SMK Muhammadiyah 6 Rogojampi Tahun Ajaran 2017/2018

\section{KAJIAN LITERATUR DAN PENGEMBANGAN HIPOTESIS}

Self-awareness adalah kemampuan untuk mengakui atau mengenal perasaan diri ataupun keadaan dimana seseorang bisa memahami dirinya sendiri dan juga merupakan syarat agar kita dapat bekerja dengan orang lain secara efektif.

Berdasarkan landasan teori diatas, maka hipotesis yang diajukan dalam penelitian ini adalah (1) konseling kelompok dengan Pendekatan behavioral teknik asertif berpengaruh meningkatkan self awareness pada siswa kelas XI di SMK 17 Agustus 1945 Muncar

(2) terdapat perbedaan penurunan perilaku seks bebas antara kelompok eksperimen dengan kelompok asertif 


\section{METODE PENELITIAN}

Menurut Sugiyono (2010:119), "Populasi adalah wilayah generalisasi yang terdiri atas obyek/subyek yang mempunyai kualitas dan kualitas dan karakteristik tertentu yang ditetapkan oleh peneliti untuk dipelajari dan kemudian ditarik kesimpulan".

Populasi yang digunakan dalam penelitian ini adalah siswa kelas XI SMK 17 Agustus 1945 Muncar tahun ajaran 2017/2018. Pengambilan sampel penelitian ini adalah siswa kelas XI yang terindikasi rendahnya self-awareness, dengan menggunakan konseling kelompok behavioral teknik latihan asertif siswa untuk meningkatkan self awareness nya. Teknik pengambilan sampel ini menggunakan Purposive Sampling.

Metode pengumpulan ini menggunakan metode observasi, wawancara, dan kuisoner. Penyebaran kuisioner perilaku seks bebas di berikan kepada 265 siswa kelas XI SMK 17 Agustus 1945 Muncar. Sebelum kuisioner di sebarkan dilakukan uji validitas isi yaitu validitasyang ditentukanolehderajatreprentativitasbutirbutir

instrumentyangdisusuntelahmewakilikese luruhanmateriyang hendakdiukurtersebut. Untukmengetahuivaliditasisikuesioner perilaku seks bebasyangdigunakan,maka perlu dilakukan penilaian ahli (expert judgement) oleh dua orang ahli. Setelah analisis validitas isi tersebut, dilanjutkan dengan melakukan uji validitas butir melalui analisis butir. Suatu angket (kuesioner) dikatakan valid jika pernyataan/pernyataan pada suatu kuesioner mampu untuk mengungkapkan sesuatu yang akan di ukur oleh kuesioner tersebut (Nurkancana, 1990: 232). Setelah validitas isi dan validitas butir dilakukan, maka selanjutnya dilakukan uji reabilitas (keandalan). Suatu kuisioner dikatakan reliabel "apabila tes tersebut menunjukkan hasil-hasil yang mantap". (Nurkanca, 1993:144).

Setelah mendapat data kusioner perilaku seks bebas akan dilakukan analisis data secara deskriptif. Data instrumen perilaku seks bebas dianalisis secara deskriptif dan dinyatakan dengan jenjang kualifikasi. Jenjang kualifikasi dikategorikan berdasarkan skor rata-rata $(\bar{X})$, mean ideal (Mi), dan standart deviasi ideal $\left(\mathrm{SD}_{\mathrm{i}}\right)$. Uji prasyarat analisis yaitu (1) uji normalitas adalah sebaran data dilakukan untuk meyakinkan bahwa data yang dihasilkan dalam penelitian benar-benar berdistribusi normal, sehingga uji hipotesis dapat dilakukan. (2) Uji homogenitas digunakan untuk mengetahui apakah kelompokkelompok sampel berasal dari populasi yang sama. Kesamaan asal sampel ini dibuktikan dengan adanya kesamaan 
varians kelompok-kelompok yang membentuk sampel tersebut. (3) Uji Hipotesis Sebagai langkah lebih lanjut dalam penelitian ini, dilakukan suatu produser analisis terhadap data-data yang diperoleh peneliti. Tujuan dari analisis data ini adalah mengungkapkan apa yang ingin diketahui dari peneliti. Dalam menganalisis data yang diperoleh selama melakukan penelitian, penulis menggunakan dua analisis statistik, antara lain (1) analisis statistik correlated data/paired sampel t-test dan (2) analisis statistik uncorrelated data/independent sampel t-test.

Dasar pengambilan keputusannya adalah : (a)Jika $\mathrm{t}$ hitung $>\mathrm{t}$ tabel, maka $\mathrm{H}_{\mathrm{o}}$ ditolak, (b) Jika $\mathrm{t}$ hitung $<\mathrm{t}$ tabel, maka $\mathrm{H}_{\mathrm{o}}$ diterima.Berdasarkan nilai probabilitinya :(1)Jika probabilitas $>0,05$ maka $\mathrm{H}_{\mathrm{o}}$ diterima, (2)Jika probabilitas $<0,05$ maka $\mathrm{H}_{\mathrm{o}}$ ditolak.Analisis statistik correlated data/paired sampel t-test dimaksudkan untuk mengetahui efektivitas atau pengaruh dari variabel bebas terhadap variabel terikat dilihat dari perbedaan pretest dengan posttest (Seniatai, Yulianto dan Setiadi, 2005:119).

\section{RANCANGAN PENELITIAN}

Penelitian ini adalah penelitian kuantitatif dengan metode experimen. Rancangan penelitian kuantitatif ini yakni quasi experimental (ekseprimen semu). Desain penelitian ini menggunakan rancangan Non equivalent Pretest-Posttest Control Group Design. Rancangan control group design dipilih dengan pertimbangan bahwa dalam eksperimen semu, tidak memungkinkan untuk merandom subjek dalam kelompok populasi secara utuh. Selanjutnya pretest dan posttest berarti memberikan tes kepada subjek sebelum dan setelah perlakuan diberikan pada masing-masing kelompok. Rancangan ini dipilih karena penelitian ini merupakan penelitian terapeutik untuk mengetahui pengaruh perlakuan terhadap variabel terikat. Artinya rancangan pretest dan posttest digunakan untuk mengetahui siswa yang kecanduan game online.

\begin{tabular}{cccc}
$\mathrm{E}$ & $\mathrm{O}_{1}$ & $\mathrm{X}$ & $\mathrm{O}_{2}$ \\
\hline $\mathrm{K}$ & $\mathrm{O}_{1}$ & - & $\mathrm{O}_{2}$
\end{tabular}

(Sumber: Dantes, 2012:97)

Gambar 02. Desain Non Equivalent Pretest-Posttest Control Group

E : kelompok eksperimen

$\mathrm{K}$ : keompok kontrol

$\mathrm{X}$ : konseling kelompok behavioral dengan teknik modeling

: konseling kelompok tanpa

teknik khusus

O1: pengamatan awal, berupa pre-test sebelum diberikan perlakuan.

$\mathrm{O} 2$ : Pengamatan akhir, yaitu pemberian post test setelah diberikan perlakuan. 


\section{KESIMPULAN}

Seks bebas dikalangan remaja bukanlah hal asing atau aneh bahkan pembahasan tentang seks bebas sudah menjadi makanan sehari - hari dikalangan remaja. Pemicu banyaknya perilaku seks bebas dikalangan remaja diantaranya, proses pendidikan yang gagal, sering melihat pronografi dan pornoaksi. Dan untuk itu, kita sebagai remaja generasi penerus bangsa yang akan datang, hendaknya menghindari perilaku seks bebas dengan cara mengikuti kegiatan yang positif, pandai - pandai dalam memilih teman dan lingkungan pergaulan, hindari nonton film-film porno.

\section{REFERENSI}

Adhiputra, A.A. Ngurah. 2014. Konseling Kelompok Perspektif Teori Dan Aplikasi. Yogyakarta: Media Akademi.

Arikunto, Suharsimi. 2006. Prosedur Penelitian: Suatu Pendekatan Praktik. Jakarta: Rineka Cipta.

Arikunto, Suharsimi. 2010. Dasar-dasar Evaluasi Pendidikan (Edisi Revisi). Jakarta: Bumi Aksara.

Candiasa, I Made. 2011. Statistik Multivariant Disertai Aplikasi SPSS. Singaraja: Undiksha Press.
Corey, Gerald (Terjemahan E. Koswara.). 2010. Teori dan Praktek Konseling dan Psikoterapi. Bandung: PT. Refika Aditama.

Dantes, Nyoman. 2012. Metode Penelitian. Yogyakarta: Penerbit Andi.

Dantes, Nyoman. 2014. Analisis dan Desain Eksperimen. Singaraja: Universitas Pendidikan Ganesha.

Hadi, Sutrisno.2002. Statistik Jilid 2. Yogyakarta: Andi Yogyakarta.

Komalasari, Gantina dkk. 2011. Teori dan Teknik Konseling. Jakarta: PT. Indeks.

Koyan, I Wayan. 2012. Statistik Pendidikan (Teknik Analisis Data Kuantitatif). Singaraja: Undiksha Press.

Mehrens, W. A \& Lehmann, I. J. 1984. Measurement and evaluation in Education and Psychology, Third Edition. New York: Holt, Rinehart and Winston.

Noor, Juliansyah. 2010. Metodelogi penelitian. Jakarta: Kencana Prenada Media Group.

Nurkancana, Wayan, 1993. Evaluasi Pendidikan. Surabaya: Usaha Nasional, Santoso, S. 2010. Statistik Multivariat. Jakarta: PT Elex Media Komputindo. 